PAWeE PIOTROWSKI

Uniwersytet Warmińsko-Mazurski

w Olsztynie

\title{
JEDNA, WIELE CZY MOŻE ŻADNA? \\ FENOMENOLOGIA W NAUKACH O WYCHOWANIU. WĄTKI FENOMENOLOGICZNE W NAUKACH \\ O WYCHOWANIU \\ - KONTEKST HISTORYCZNY
}

\begin{abstract}
AвStRact. Piotrowski Paweł, Jedna, wiele czy może żadna? Fenomenologia w naukach o wychowaniu. Watki fenomenologiczne w naukach o wychowaniu - kontekst historyczny [Is There One, Many or Maybe There Is No? Phenomenology in Educational Sciences]. Studia Edukacyjne nr 45, 2017, Poznań 2017, pp. 369385. Adam Mickiewicz University Press. ISSN 1233-6688. DOI: 10.14746/se.2017.45.24

The article presents and reflects on the presence of some phenomenological motifs in educational sciences research and investigations. The text focuses on historical, methodological and structural context of this connection. An attempt is made to assert qualification conditions for each of the answer options mentioned in the title, as possible answers to the question about the connection between phenomenology and educational science. An attempt to define reasons for each of the above answers is taken as well.
\end{abstract}

Key words: educational sciences, philosophy of education, philosophy and pedagogy, phenomenology

„Pozycja fenomenologii w pedagogice nie jest jeszcze wystarczająco sprecyzowana i ustabilizowana" stwierdziła Krystyna Ablewicz ${ }^{1}$ w jednym ze stosunkowo nielicznych w polskiej pedagogice opracowań poświęconych fenomenologii $\mathrm{w}$ odniesieniu do nauk o edukacji. Warto więc może na początek rzucić okiem na historyczny kontekst odnośnej kwestii, a właściwie na pewien jego wycinek. Aloys Fischer był uczniem Theodora Lip-

${ }^{1}$ K. Ablewicz, Hermeneutyczno-fenomenologiczna perspektywa badań w pedagogice, Kraków 1994, s. 68-69. 
psa, przedstawiciela tak zwanej fenomenologii monachijskiej, w której silnie zaznaczały się wpływy fenomenologii Husserla². Współpracował również blisko z inną znaczącą postacią ruchu fenomenologicznego, to jest z Aleksandrem Pfänderem. Żył dość krótko i nie pozostawił zbyt wielu dzieł, jednak to, które najbardziej oddawało bodaj ducha pierwszej fenomenologii nie zyskało wśród współczesnych Fischerowi ani większego oddźwięku, ani uznania dla autora. Ów tekst Pedagogika deskryptywna odkryty został na nowo (choć właściwie w przedstawionej sytuacji było to pierwsze odkrycie), przez niemieckich filozofów wychowania zainteresowanych adaptacją fenomenologii do obszaru badawczego nauk o edukacji, takich jak Danner, Oppolzer, Plöger czy Bollnow³ , dopiero pod koniec lat sześćdziesiątych XX wieku. We wspomnianej pracy Fischer prezentował pewien sposób podjęcia postępowania badawczego wywiedzionego z fenomenologii Husserla, $\mathrm{w}$ tym przede wszystkim redukcji, w celu ejdetycznego i nieredukcyjnego opisu najpierw regionu nauki o wychowaniu, a w dalszej kolejności fenomenu wychowania i kształcenia. Do treściowego wątku pracy Fischera trzeba tu będzie jeszcze na chwilę powrócić, jednak w tym miejscu warto zwrócić uwagę na kwestię historyczną, jeżeli można tak powiedzieć, czyli na to, iż dopiero po blisko półwieczu jego propozycja fenomenologicznego podejścia do badań nad edukacją wzbudziła zainteresowanie badaczy rzeczywistości wychowawczej i to też tylko tych, którzy interesowali się filozoficznym aspektem tychże badań. Refleksja nad edukacją uprawianą w ramach wyodrębnionej dziedziny, jaką jest pedagogika (jest bowiem taka refleksja uprawiana również niejako przy okazji rozważań filozoficznych, $\mathrm{w}$ sensie klasycznym filozoficznych, czyli nie zawężonych do pewnej regionalności swojego przedmiotu) reaguje chyba silniej niż inne dziedziny, w tym filozofia, na różnego rodzaju dziejowe zawirowania. Przyczyna takiego stanu rzeczy tkwi, być może, w ostatecznie praktycznym, jak by tego postulatu nie rozumieć, ukierunkowaniu badań i namysłu nad edukacją, a co się z kolei z tamtym wiąże, nieustającej tendencji do podejmowania prób ideologicznego zawłaszczania tego obszaru. Brak tu miejsca na podjęcie próby dowiedzenia czy nawet obrony tego historiozoficznego poniekąd twierdzenia, niemniej faktem jest, że do wspomnianego wyżej schyłku szóstej dekady XX wieku podejście o proweniencji fenomenologicznej nie było obecne w naukach o wychowaniu w taki sposób, w jaki dało się zaobserwować, co prawda z okresowo wzrastającym i słabnącym nasileniem, po tym okresie. Nie było obecne w taki sposób, choć w ogóle było oczywiście obec-

${ }^{2}$ H. Spiegelberg, The phenomenological movement. A historical introduction, t. 1, The Hague 1965, s. 171-172. Interesujące, że nawet H. Spiegelberg, niekwestionowany autorytet w zakresie historii fenomenologii, niewiele pisze na temat działalności naukowej A. Fischera.

${ }^{3}$ K. Ablewicz, Hermeneutyczno-fenomenologiczna perspektywa, s. 70-71. 
ne za sprawą prac tych działających wówczas jeszcze filozofów, których zachodni komentatorzy i systematycy współczesnej filozofii określają mianem twórców fenomenologii egzystencjalnej, fenomenologii hermeneutycznej, czy wreszcie fenomenologicznego personalizmu, bo i takie określenie w niektórych systematykach można znaleźć ${ }^{4}$, czyli takich jak Jean-Paul Sartre, Emanuel Levinas, Paul Ricoeur, Gabriel Marcel, Hans-Georg Gadamer, Maurice Merleau-Ponty, czy w obszarze filozoficznie opracowywanej socjologii Alfred Schütz i jego główny uczeń, kontynuator i zarazem oponent odnośnie pewnych istotnych niuansów, również tych o fenomenologicznym pochodzeniu, Harold Garfinkel. Tu rzeczywiście wątki fenomenologiczne, także odnoszone do problematyki szeroko pojętej edukacji, są obecne niejako z pierwszej ręki. Niemniej już na tym etapie zasadne jest pytanie: czy to jeszcze fenomenologia? Jeżeli takie pytanie zasadne jest już tutaj, o ile bardziej uzasadnione jest jego stawianie w odniesieniu do okresu późniejszego i kontynuacji, adaptacji, interpretacji, translacji czynionych na obszarze instytucjonalnej, w sensie kuhnowskim, nauki o edukacji. Wszelako zainteresowanie fenomenologiczną filozofią i jej pedagogiczną recepcją, czy może interferencją, wzrosło wyraźnie dopiero, jak wspomniano, pod koniec lat sześćdziesiątych XX wieku. Nie dotyczy to zresztą tylko fenomenologii, czy raczej fenomenologicznych wątków i inspiracji, ale także szeregu innych antyscjentystycznych i nie utylitarystycznych projektów filozoficznych, takich jak, w pierwszym rzędzie, hermeneutyka, a także personalizm, egzystencjalizm czy filozofia dialogu. Najsilniej zresztą zaznaczyły swoje wpływy hermeneutyka i bodaj personalizm. Często wątek fenomenologiczny był nawet obecny jako swoisty wstęp do hermeneutyki, o czym jeszcze będzie mowa niebawem. Rzuca się w oczy zbieżność w czasie tego zwrotu w kierunku wspomnianych filozoficznych źródeł $\mathrm{w}$ obszarze instytucjonalnej pedagogiki, z nasileniem ruchów kontestujących zastaną kulturę, której istotny składnik stanowi edukacja. Fala sprzeciwu i krytyki napływa z wielu stron, żeby wspomnieć tylko kontrkultury młodzieżowe, kontestacje studenckie, drugą falę feminizmu, sztukę kontestatorską, jednak w każdym z tych przypadków pośrednio lub wprost kwestionowana jest edukacja jako instytucja społeczno-kulturowa współodpowiedzialna za kształtowanie zakresu i sposobu partycypacji pokoleń, grup i jednostek w kulturze i społeczeństwie. Ta czasowa koincydencja oskarżycielskiej krytyki opresyjności jednowymia-

${ }^{4}$ Zob. np. Th.R. Flynn, Philosophy of existence 2, [w:] Twentieth-Century Continental Philosophy, red. R. Kearney, London - New York 2005, s. 78-79; F.-D. Sebbah, French Phenomenology, [w:] A Companion to Phenoemnology and Existentialism, red. H.L. Dreyfus, M.A. Wrathall, Malden - Oxford - Carlton 2006, s. 48-67. W tym ostatnim tekście, poza sygnalizowanymi wyżej, można znaleźć inne jeszcze ciekawe dookreślenia fenomenologii, na przykład „radykalna fenomenologia”, „materialna fenomenologia” (s. 51), czy nawet „sporadyczna fenomenologia” (s. 57). 
rowej, transmisyjnej edukacji, ze zwrotem instytucjonalnej nauki o wychowaniu ku antyscjentystycznym nurtom współczesnej filozofii, by znaleźć w nich pomoc dla nowego odczytania sensu działań edukacyjnych i istoty edukacji, jest na tyle podejrzana, że trudno nie doszukiwać się tu związku przyczynowego.

Określeń „sens działań edukacyjnych" i „istota edukacji” użyto tu celowo, jako że kojarzą się właśnie z fenomenologiczną filozofią. I to skojarzenie na początku lat siedemdziesiątych było, jak się zdaje, w obszarze instytucjonalnej nauki o wychowaniu, dosyć powszechne. Powszechne i pobieżne, choć łatwo zrozumieć, że pytanie: „czy to rzeczywiście fenomenologia?” musiało się jawić jako zdecydowanie drugorzędne w stosunku do wspomnianych przed chwilą pytań, na które zaczęto dość gorączkowo poszukiwać odpowiedzi. Zresztą podobną tendencję można było zaobserwować również na polu wiodącej nauki społecznej, czyli socjologii. Znamienne jest tu, co napisali na ten temat Ted Benton i Ian Craib, gdyż w pewnym może uproszczeniu, ale dosyć adekwatnie oddaje sytuację terminu „fenomenologia" i jego rozmaitych form gramatycznych w naukach określanych mianem społecznych i takichż badaniach uprawianych w latach siedemdziesiątych w Europie Zachodniej i Stanach Zjednoczonych:

Pod koniec lat 60. i w latach 70. termin "fenomenologia” bądź "fenomenologiczny” był powszechnie stosowany wśród socjologów. „Podejście fenomenologiczne” czy "metodę fenomenologiczną" zestawiano z czymś, co uważano za dominującą "pozytywistyczną" metodę w naukach społecznych. Podajemy te wyrażenia w cudzysłowie, ponieważ często posługiwano się nimi dość swobodnie - to drugie oznaczało wszelkie badanie z wykorzystaniem statystyki, pierwsze zaś podejścia, które brały pod uwagę punkt widzenia aktora. Terminy te są obecnie mniej popularne, lecz do tej pory używa się ich czasem w ten sposób w socjologii czy psychologii społecznej ${ }^{5}$.

Opisaną sytuację terminu „fenomenologia” potwierdza, a i niemało się do zadomowienia takiego pojęcia fenomenologii w naukach społecznych przyczyniła, opracowana przez Gibsona Burella i Garetha Morgana w 1979 roku i wielokrotnie później przedrukowywana w różnych opracowaniach (także tych dotyczących podstaw metodologicznych dla badań nad edukacją) mapa współczesnych paradygmatów w badaniach społecznych. Tak oto wyglądało wzajemne usytuowanie głównych podejść do badań społecznych oraz podstawowe cechy tych podejść według Burella i Morgana:

Jak widać, po wyrażenia "fenomenologia”, "fenomenologiczny” sięgano bez zbytniej dbałości o terminologiczną ścisłość, pozostawiając kwestię uzasadnienia adekwatności nazwy na uboczu, jako sprawę drugorzędną. To samo

${ }^{5}$ T. Benton, I. Craib, Filozofia nauk społecznych. Od pozytywizmu do postmodernizmu, przekł. L. Rasiński, Wrocław 2003, s. 99. 


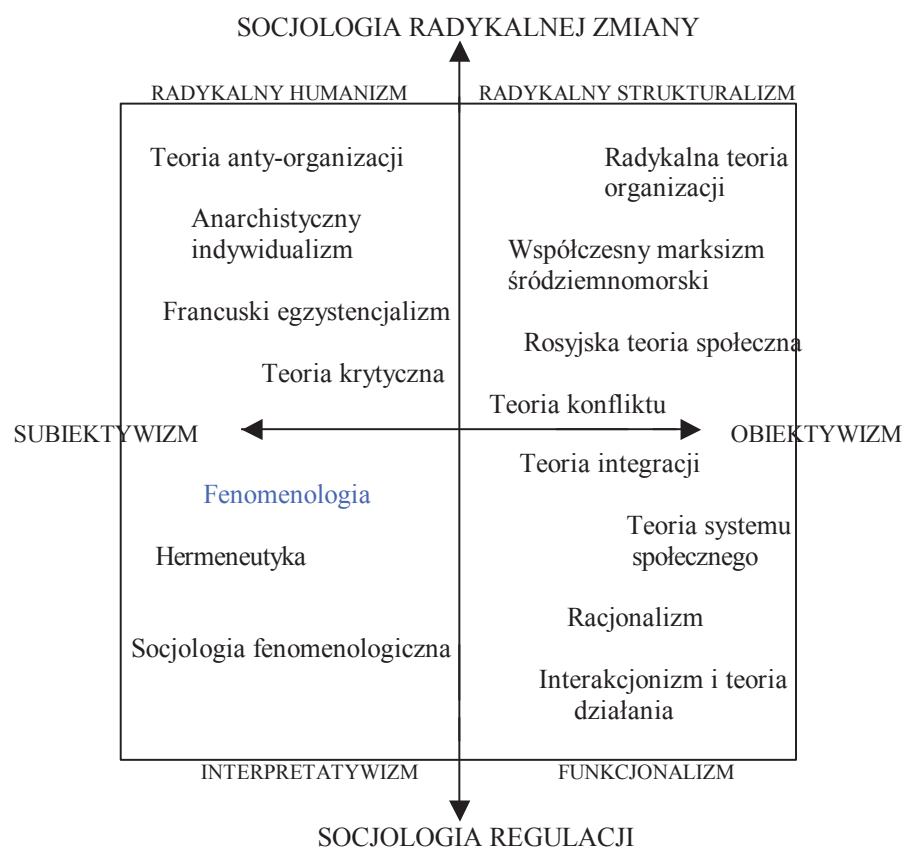

Źródło: R.G. Paulston, Pedagogika porównawcza jako pole nakreślania konceptualnych map teorii i paradygmatów, przekł. Z. Melosik, K. Sobolewska-Myślik, [w:] Alternatywy myślenia o/dla edukacji. Wybór tekstów, red. Z. Kwieciński, Warszawa 2000, s. $90^{6}$

dotyczy zresztą i innych nazw przywołanych na prezentowanej mapie, z których część została skonstruowana ad hoc i nie przyjęła się, nie ostała w systematyzacjach prądów i kierunków socjologicznych. Klasyfikacja dokonana przez Paulstona miała, jak widać, charakter doraźny i prowizoryczny. I jako coś doraźnego i prowizorycznego przetrwała ponad dekadę, wielokrotnie

${ }^{6}$ Polski pierwodruk tekstu Paulstona, do którego załączony jest zacytowany schemat w: Spory o edukację. Dylematy i kontrowersje we wspótczesnych pedagogiach, red. Z. Kwieciński, L. Witkowski, Instytut Badań Edukacyjnych, Warszawa 1993, s. 22-50. Z kolei sam oryginalny tekst Rolanda G. Paulstona, o którym mowa powyżej, zaprezentowany został po raz pierwszy w 1992 roku na Kongresie Towarzystwa Pedagogiki Porównawczej i Międzynarodowych Badań Edukacyjnych w Annapolis, a opublikowany rok później. Z kolei jednak, jak zaznacza sam Paulston, opracowując odnośny schemat opierał się na pracy G. Burella i G. Morgana, Sociological paradigms and organisational analysis. Elements of the sociology of corporate life, wydania z roku 1989 (Johnatan H. Turner przywołuje uproszczoną wersję tegoż schematu, zaczerpniętą z pierwszego wydania pracy Burella i Morgana z 1979 roku w swojej Strukturze teorii socjologicznej [polskie wydanie w przekładzie J. Szmatki, PWN, Warszawa 1985, s. 23]. W wersji Turnera, na mapie nie ma przedstawionych teorii i nurtów, nie ma zatem ani teorii organizacji, ani hermeneutyki, ani fenomenologii) oraz posiłkował się propozycją A. Tjedvolla, przedstawioną na tej samej konferencji w Annapolis, na której Paulston zaproponował pierwotną wersję tekstu, z którego odnośny schemat pochodzi. 
przedrukowywana i entuzjastycznie przyjęta w polskiej pedagogice, która akurat $w$ tamtym czasie, to jest na początku lat dziewięćdziesiątych XX wie$\mathrm{ku}$, czegoś takiego potrzebowała.

Potrzebowała, ponieważ zjawisko podobne do tego, jakie zaznaczyło się $\mathrm{W}$ instytucjonalnej pedagogice zachodniej na początku lat siedemdziesiątych miało miejsce $\mathrm{w}$ pedagogice polskiej w latach dziewięćdziesiątych XX wieku. I tu także obserwowalna jest zbieżność w czasie z wydarzeniami społecznymi, które określa się mianem transformacji ustrojowej. Tym też tłumaczono to specyficzne zapóźnienie względem rozwijanych w krajach zachodnich nauk o wychowaniu, wyrażające się powtórzeniem podobnej sytuacji, to znaczy wyłonieniem się pluralizmu teoretycznego i metodologicznego, charakteryzującego się nadto zwróceniem ku niescjentystycznym projektom filozoficznym w poszukiwaniu inspiracji i źródeł ${ }^{7}$. Wyłonieniem się pluralizmu, poprzedzonym kryzysem formacyjnym, związanym z załamaniem zaufania do rozwijanej dotychczas teorii pedagogicznej i uzasadnianej przez nią praktyki. Mówiąc ściślej, wspomniane opóźnienie, wyrażające się występowaniem analogicznych zjawisk jak w zachodniej pedagogice, tyle że trzydzieści lat później, tłumaczono bezwzględną dominacją w teorii i praktyce edukacyjnej na obszarze bloku wschodniego tak zwanej pedagogiki socjalistycznej, której filozoficzną podstawę stanowił materializm dialektyczny, dający prymat zbiorowości przed jednostką i lekceważący problematykę podmiotowości, zaś podstawę psychologiczną stanowił behawioryzm ${ }^{8}$. Można by powiedzieć, iż oparta na materializmie dialektycznym, jako na swoim filozoficznym fundamencie, pedagogika socjalistyczna redukowała jednostkową świadomość podmiotu do pewnego rodzaju partycypacji w świadomości klasowej, co dawało asumpt do rozwoju empirycystycznej, scjentystycznej socjologii, będącej swego rodzaju stopniem pośredniczącym między filozofią a nauką o wychowaniu, rozumianym jako ważna forma praktyki społecznej i do tego rozumienia ograniczonym. Jako filozofia, mówiąc w pewnym uproszczeniu, ufundowana na doświadczeniu podmiotu i od tegoż doświadczenia wychodząca, fenomenologia jest $\mathrm{z}$ takim podejściem, jaki reprezentuje "socjalistyczna teoria wychowania”, niezbieżna. To samo można powiedzieć o co najmniej kilku innych kierunkach filozofii, ale nas interesuje fenomenologia. Wszelako z faktu niezbieżności z dominującym nurtem, nawet jeśli dominującym dlatego, że promowa-

7 Zob. Z. Kwieciński, Teorie pedagogiczne okresu przesilenia. Strategie przezwyciężania polskiego „opóźnienia”, Kultura i Edukacja, 1993, 1(3). Por.: Z. Kwieciński, Między ortodoksją a heterogenicznościa teorii pedagogicznych. Ku strategiom pokonywania polskiego „opóźnienia”, [w:] Stare i nowe dylematy teorii wychowania, red. J. Górniewicz, Torun 1993, s. 7-11.

${ }^{8}$ Zob. T. Hejnicka-Bezwińska, W poszukiwaniu tożsamości pedagogiki: świadomość teoretyczna i metodologiczna wspótczesnej pedagogiki polskiej (geneza i stan), Bydgoszcz 1989. 
nym przez władze polityczne, nie wynika jeszcze, nawet pośrednio, uzasadnienie niemożności zainteresowania tamtymi podejściami, ich badania i rozwijania. Wyjaśnienie wspomnianego zapóźnienia, przywoływane często $\mathrm{w}$ pierwszych latach ostatniej dekady $\mathrm{XX}$ wieku przez czołowe postaci polskiej pedagogiki, byłoby może przekonujące, gdyby blisko półwiecze istnienia Polski Ludowej wypełniał szczelnie monolityczny okres stalinizmu, jednak skądinąd wiadomo, że tak nie było. W tym kontekście wart jest wspomnienia casus Romana Ingardena, największego przecież polskiego fenomenologa właśnie. Jak czytamy we wspomnieniach o Ingardenie pióra M. Gołaszewskiej, w pierwszej powojennej dekadzie doświadczył on wszelkich represji, jakie mogą spotkać kogoś, kto chce rozwijać inny, niż ,jedynie słuszny" paradygmat badawczy, począwszy od przymusowego uczestnictwa w pochodach pierwszomajowych po zwolnienie z pracy na uniwersytecie $^{9}$. Oczywiście, że nie wolno pomijać ani lekceważyć traktowania, z jakim spotkał się w pierwszej dekadzie lat powojennych ten jeden $\mathrm{z}$ najwybitniejszych polskich filozofów współczesnych i jego dzieło. Niemniej od razu trzeba też zaznaczyć, że jak pisze Gołaszewska:

Po Październiku 1956, nastąpiła „odwilż polityczna”, także na uniwersytetach, i wówczas Ingarden rozpoczął wykłady na UJ od drugiego semestru 1957, a następnie został dziekanem Wydziału Filozoficzno-Historycznego. Zaczęto wznawiać i wydawać książki profesora, rozpoczęte zostało wydawanie wielotomowych Dzieł filozoficznych Romana Ingardena. Mógł osobiście brać udział w międzynarodowych kongresach i sesjach filozoficznych, korzystać z zagranicznych zaproszeń na wykłady ${ }^{10}$.

Fenomenologiczna filozofia Ingardena była rozwijana także w czasach „jedynej słusznej filozofii”, jaką przecież nie była fenomenologia. Dlatego, wyjaśnianie zapóźnienia formacyjnego polskiej pedagogiki w stosunku do tej rozwijanej na przykład na zachodzie Europy, poprzez odwołanie do dominującej roli pedagogiki socjalistycznej, nie jest całkiem przekonujące. Tym bardziej że przecież, rzadko bo rzadko, ale jednak pojawiały się i były dostępne prace, w których dało się zauważyć poszukiwania projektów alternatywnych wobec proponowanego przez pedagogikę socjalistyczną, jak choćby niektóre prace Karola Kotłowskiego, nawiązujące do pedagogiki kultury, u swych źródeł wywiedzionej z heglowskiego idealizmu prace Bogdana Nawroczyńskiego, Zygmunta Mysłakowskiego, czy właśnie do fenomenologii sięgające propozycje Władysława Cichonia, późnego ucznia Romana Ingardena. Ta obecność podejść niezbieżnych z dominującym była też, chyba nawet bardziej, zauważalna w filozofii. Dlatego jako bardziej przekonujące jawi się inne wyjaśnienie, wspólne zarówno dla zwrotu ku

\footnotetext{
${ }^{9}$ M. Gołaszewska, Roman Ingarden. Życie i dzieło, Kraków 1993, s. 8.

${ }^{10}$ Tamże.
} 
antyscjentystycznym nurtom filozofii w latach siedemdziesiątych ubiegłego wieku w Europie Zachodniej i Stanach Zjednoczonych, jak i w latach dziewięćdziesiątych w Polsce. Otóż, wydaje się, że w obu wymienionych przypadkach przyczyną było wyczerpanie się możliwości dalszego eksploatowania podejść zakładających fizykalistyczną w pewnym sensie mierzalność parametrów zjawisk edukacyjnych i możliwość modyfikowania wartości tychże parametrów poprzez odpowiednio przygotowane działanie. Nie tyle chodzi zresztą o intelektualne czy teoretyczne wyczerpanie takiego podejścia, choć niewątpliwie w wymiarze teoretycznym głośne prace dwudziestowiecznych filozofów nauki, takich jak Karl Popper, Thomas Kuhn, Imre Lakatos czy Paul Feyerabend odegrały tu pewną istotną rolę. Idzie jednak przede wszystkim o wyczerpanie w aspekcie funkcjonalnym czy instrumentalnym. Jak bowiem dalej transmitować kulturę, kiedy ludzie deklarują, że ją odrzucą? Można więc powiedzieć, że rozwijany dotąd projekt pedagogiki przestał być adekwatny do świata społecznego i kulturowego, na który przecież jest finalnie skierowany i jako taki wymagał zastąpienia, co musiało zostać poprzedzone sygnalizowanym tu wcześniej pytaniem o sens edukacji. Polskie opóźnienie $\mathrm{w}$ tej materii bierze się z tego, iż ów projekt okazał się w tym kontekście społecznym i kulturowym bardziej żywotny z jakichś powodów, na których rozważenie nie ma tu miejsca. Ale jedną istotną kwestię trzeba w związku z tym koniecznie odnotować. Otóż, krakowska badaczka Krystyna Duraj-Nowakowa w artykule "Samookreślenie pedagogów" przedstawiła swego czasu historyczny rozwój nauki o wychowaniu jako drogę „od przednaukowej pedagogiki przez stadium fenomenologiczne do nomotetycznego"11. Jeżeli, jak można mniemać, choć autorka tego wyraźnie nie stwierdza, stadium nomotetyczne rozumieć jako okres rozwoju pedagogiki naukowej (w naszkicowanym wyżej sensie), to $\mathrm{w}$ świetle tego, co tu zostało dotąd powiedziane, stadium fenomenologiczne należałoby $\mathrm{w}$ tej periodyzacji umieścić nie przed nim, a właśnie po, jako to co nastąpiło po kryzysie naukowej - w znaczeniu: scjentystycznej - pedagogiki.

Kierując się ku próbie udzielenia jakiejś odpowiedzi na pytanie, ile fenomenologii można odnaleźć w badaniach edukacyjnych, warto powrócić jeszcze na chwilę do kwestii prowizoryczności typologicznych map paradygmatów występujących $\mathrm{w}$ naukach społecznych, a do takich zaliczano niemal powszechnie nauki o wychowaniu w okresie o którym mowa i zauważyć, że przyczyniły się też one, jak na przykład ta zaproponowana przez Rolanda Paulstona, do pewnych nieporozumień, których ofiarą padło pojmowanie fenomenologii przez niektórych przedstawicieli tychże nauk

${ }^{11}$ K. Duraj-Nowakowa, Samookreślenie pedagogów, [w:] Rozwój pedagogiki ogólnej. Interpretacje i ograniczenia kulturowe oraz poznawcze, red. A. Bogaj, Warszawa-Kielce 2001, s. 141. 
społecznych. Ulokowanie fenomenologii na obszarze mapy reprezentującej subiektywizm/interpretatywizm jest zasadne, ale wymaga terminologicznych uściśleń, których Paulston nie uczynił i nie czynili ich zazwyczaj również inni autorzy takich typologii. Otóż, po pierwsze, co innego oznacza interpretatywizm etnometodologii - paradygmatu nauk społecznych, $\mathrm{w}$ tym w pierwszym rzędzie współczesnej mikrosocjologii i etnografii, czymś innym interpretatywizm $\mathrm{w}$ odniesieniu do zakładających nieskończoną sieć interpretacji radykalniejszych odmian hermeneutyki (w znaczeniu, w jakim określenia "radykalna” używał w odniesieniu do hermeneutyki Jurgen Habermas, nie zaś na przykład John Caputo), wreszcie czymś innym jest interpretatywizm odniesiony do kategorii definicji sytuacji społecznej w określanej jako fenomenologiczna socjologii Alfreda Schutza i później Harolda Garfinkla, a idąc jeszcze dalej - w dramaturgicznej socjologii Ervinga Goffmana. No i wreszcie co innego musi znaczyć interpretatywizm i w ogóle pojęcie interpretacji $\mathrm{w}$ odniesieniu do fenomenologicznej redukcji świata uteoretyzowanego i świata życia codziennego w fenomenologii jako filozofii. Podobnych trudności i nieporozumień nastręczyła kategoria „subiektywizm”. Wypada bowiem rozróżnić co najmniej między ontologicznym, jeśli tak można go nazwać, subiektywizmem, w szczególności w odniesieniu do świata społeczno-kulturowego i epistemologicznym subiektywizmem. O ile ten pierwszy wskazuje na aktywną rolę podmiotu w tworzeniu bytu społecznego, lub inaczej mówiąc zakłada, że świat współkonstytuowany jest z udziałem podmiotu ujmującego ten świat czy jego fragment (w pierwszej kolejności poznawczo), o tyle ten drugi dotyczy raczej aktywnej roli podmiotu w tworzeniu prawdy o tymże świecie, co czyni ją relatywną i nieadekwacyjną. Oba te aspekty niekoniecznie muszą być ze sobą jednoznacznie powiązane i w przypadku fenomenologii, jak również fenomenologicznej socjologii, przynajmniej tej rozwijanej według projektu A. Schutza - nie są. Ale na przykład, już w przypadku niektórych projektów określanych mianem postmodernistycznych - są powiązane. Nierozróżnienie tych dwu znaczeń subiektywności prowadziłoby (i prowadziło, a niekiedy nadal prowadzi) do zaliczenia stanowisk zakładających, iż każdy konkretny podmiot ma swoją konkretną prawdę komunikowalną, bądź nie, do jednego typu racjonalności badawczej z tymi, które uznają co najmniej intersubiektywność. Taka sytuacja zachęcała niekiedy $\mathrm{w}$ badaniach prowadzonych $\mathrm{w}$ obszarze nauk społecznych do powoływania się na mglistą metodologię fenomenologiczną jako swoistą kurtynę, która miała zabezpieczać przed ewentualną możliwością krytyki wytykającej brak metodyczności w postępowaniu badawczym. I miałby rację czujny krytyk, stwierdzając w odniesieniu do takich przedsięwzięć, że żadnej fenomenologii tu nie ma. 


\section{Pedagogika bez fenomenologii}

Należy jednak oddać sprawiedliwość, że tego typu nieporozumienia są sprawą dość marginalną i nie mogą być argumentem przesądzającym o słuszności twierdzenia, iż w obszarze nauk o wychowaniu i badań nad edukacją mamy do czynienia nie z jedną i nie $z$ wieloma fenomenologiami, ale właśnie z żadną. Nie może też na rzecz takiej opcji odpowiedzi przesądzać konstatowany przez Krystynę Ablewicz fakt, od którego odnotowania zaczęto niniejsze rozważania, że pozycja fenomenologii $\mathrm{w}$ pedagogice nie jest jeszcze wystarczająco ustabilizowana, bo takie stwierdzenie można by nawet zaryzykować w odniesieniu do filozofii. Niemniej stosunkowo rzadka obecność wątków odwołujących się do fenomenologii na obszarze nauk o edukacji daje do myślenia. Chociaż tu także zauważalna jest pewna prawidłowość. Mianowicie, przeglądając choćby prace Herberta Spiegelberga czy Roberta Sokolowskiego, charakteryzujące powojenny rozwój filozofii fenomenologicznej, bardzo łatwo zauważyć, że kontynuacje i nawiązania do tej filozofii najsilniejsze i najliczniejsze są w Niemczech, czy mówiąc ogólniej w niemieckojęzycznej filozofii, oraz we Francji, w innych zaś państwach i regionach są nieporównywalnie słabsze. A twierdzą tak przecież badacze nie należący do tych, wymienionych jako dominujące $\mathrm{w}$ tym zakresie, tradycji kulturowo-językowych. I podobnie rzecz się ma z obecnością wątków fenomenologicznych (czy też - nie rozstrzygając jeszcze tej kwestii - quasi-fenomenologicznych ewentualnie pseudo-fenomenologicznych) w pedagogice - najwyraźniejsza jest ona $\mathrm{w}$ nauce o wychowaniu uprawianej w niemieckim obszarze językowym. Tym niemniej, wypada zgodzić się z Krystyną Ablewicz, że chociaż wzmianka o fenomenologii pojawia się w większości niemieckojęzycznych opracowań systematyzujących podejścia teoretyczne i metodologiczne we współczesnej pedagogice i mimo że niektórzy niemieccy badacze edukacji używają do określenia swoich propozycji ryzykownych dość określeń „pedagogika fenomenologiczna" lub nawet "fenomenologia pedagogiczna" ${ }^{12}$, to jednak generalnie nie jest fenomenologia częstym źródłem inspiracji dla pedagogów, $\mathrm{w}$ porównaniu $\mathrm{z}$ innymi podejściami, $\mathrm{z}$ hermeneutyką i koncepcjami wywiedzionymi z interakcjonistycznej socjologii na czele. To, rzecz jasna, nie jest żadna mocna przesłanka, aby powątpiewać na jej podstawie w możliwość pedagogicznej adaptacji fenomenologii, ale stanowi wystarczający pretekst do wyartykułowania takiej opcji jako prowokującej pytanie o warunki uznania twierdzenia, iż nie ma żadnej fenomenologii w badaniach edukacyjnych. Jednoznaczna odpowiedź tej treści byłaby uprawomocniona przede wszystkim nie budzącymi wątpliwości argumentami na rzecz braku możliwości pozy-

\footnotetext{
${ }^{12}$ K. Ablewicz, Hermeneutyczno-fenomenologiczna perspektywa badań, s. 68.
} 
tywnego związku nauki o wychowaniu i fenomenologii. A to występowałoby najsilniej w wypadku, gdyby ów związek był negatywny, w tym sensie, że jedno wykluczałoby drugie. I rzeczywiście, w pewnej perspektywie można wskazywać na antynomiczność tych dwu obszarów: fenomenologii i pedagogiki, czy raczej fenomenologii i edukacji, która jest nie tylko przedmiotem badań pedagogiki, ale i przedmiotem jej troski. O ile bowiem dla postępowania fenomenologicznego niezbywalne jest swego rodzaju oczyszczenie świadomości podmiotu $\mathrm{z}$ teoretycznego nastawienia, będącego w niemałym stopniu efektem edukacji, wychowania i kształcenia oraz z naturalnego nastawienia, w którym, przynajmniej po części, można dostrzegać rezultat socjalizacji, zwłaszcza tej pierwotnej, o tyle uzyskanie przez twierdzenia pedagogiczne statusu apodyktycznie pewnych uzasadniałoby dążenie do zabezpieczenia podmiotu przed jakimikolwiek, nawet chwilowymi i doraźnymi redukcjami tych nastawień, przed jakimkolwiek zawieszeniem ich obowiązywania. Pewność twierdzeń pedagogiki uzasadniałaby wyłączenie z dopuszczalnej i zalecanej krytyczności właśnie tego wszystkiego, co jest efektem edukacji opartej na tych twierdzeniach (które byłyby czymś więcej, niż kartezjuszowskie cogito). Dychotomia ta, skądinąd na swój sposób interesująca, sama się jednak znosi i to za sprawą zabezpieczających jej możliwość warunków. Dysponowanie bowiem przez pedagogikę twierdzeniami posiadającymi walor apodyktycznie pewnej prawdziwości wyklucza potrzebę redukcji fenomenologicznej i w ogóle fenomenologii jako poszukującej poznania, któremu przysługuje właśnie taka prawdziwość. Inaczej mówiąc: dysponująca takimi niepodważalnie prawdziwymi twierdzeniami nauka o wychowaniu sama byłaby maksymalistycznym projektem fenomenologii i bodaj czymś jeszcze więcej. I wówczas rzeczywiście nie byłoby potrzeby docierania do opisu sensu jawienia się świadomości świata, bo przecież takim poszukiwanym, źródłowym sensem dysponowałby podmiot za sprawą edukacji, a pytanie o tożsamość istotowych sensów odkrywanych na drodze fenomenologicznej i transcendentalnej redukcji oraz sensów udzielonych podmiotowi, jeśli można tak to określić, w procesach edukacji, byłoby nawet jakoś niestosowne, degradujące dla człowieka, bo to tak jakby pytać ciężarną kobietę, kto jest matką dziecka, które ona za jakiś czas urodzi.

Druga możliwość jednoznacznego zanegowania związków pedagogiki i fenomenologii jest uzależniona od rozstrzygnięć dotyczących samej fenomenologii. To dość trywialna możliwość, ale trzeba ją odnotować, tym bardziej że z pewnego punktu widzenia jest ona bardzo prawdopodobna. Mianowicie, nie ma i nie może być żadnego związku między obszarem badań nad edukacją i fenomenologią, jeżeli nie ma fenomenologii. Albo nie ma i nigdy nie było, w tym sensie że - odwołując się do teorii przedmiotu Meinonga i ontologii Ingardena - jedynie subsystowała przez pewien czas jako pewien 
obiekt czysto intencjonalny z klasy przedmiotów niemożliwych i ewentualnie subsystuje posfaktualnie jako projekt epistemologicznego ugruntowania wiedzy przez dotarcie do poznania posiadającego walor oczywistości i apodyktycznej pewności. Dotarcie, które jest niemożliwe do realizacji, co czyni niemożliwym cały ów projekt i skazuje go na wspomniany sposób subsystowania. Ewentualnie druga możliwość, oparta na uznaniu, że fenomenologia to odważny, maksymalistyczny projekt filozoficzny Edmunda Husserla, mający na celu epistemologiczne ugruntowania wiedzy przez dotarcie do poznania posiadającego walor oczywistości i apodyktycznej pewności. Nawet bez rozstrzygania, czy był to projekt możliwy do realizacji, wypada uznać, że fenomenologii tak pojętej nie ma, w każdym razie już nie ma, istnieje postfaktualnie. Gdyby nawet przyjąć, że można go aktualizować $i$ to nie będąc nawet Edmundem Husserlem, to jednak musiałby to być projekt równie maksymalistyczny i równie ogólny, zwrócony ku alternatywie typu wszystko albo nic, a zatem nie dający się przykroić do potrzeb i ram określonej dziedziny, nie tylko więc nauk o wychowaniu, ale w ogóle żadnej nauki, jak również żadnego wyspecyfikowanego obszaru badawczego dyscyplin o kwestionowanym statusie naukowym.

Z drugiej strony empirycznych śladów obecności wątków fenomenologicznych czy quasi-fenomenologicznych w naukach o wychowaniu nie można lekceważyć, tym bardziej że raczej trudno uznać, iż jest spełniony któryś ze wskazanych wyżej warunków, uprawniających do kategorycznego stwierdzenia, iż żadna fenomenologia nie jest i nie może być obecna w naukach o edukacji. Nawet gdyby brakowało empirycznych śladów takiej obecności, to konstatacja takiego stanu rzeczy byłaby mało wiążąca, bez określenia powodów i próby stwierdzenia, czy są to powody konieczne i trwałe. Bo co by znaczyło w gruncie rzeczy takie stwierdzenie faktu nieobecności? Mogłoby mieć różne znaczenia: że nie ma w tej chwili, że nie ma jeszcze, że nie ma już, że nie ma ostatnio, wreszcie - że nie są zbyt wyraźne. W najnowszym opublikowanym w Polsce tekście na temat obecności fenomenologii w pedagogice, którego autorem jest Mirosław Kowalski z Uniwersytetu Zielonogórskiego, można prześledzić dość kuriozalną drogę diagnozowania takiej nieobecności. Otóż, autor wskazuje dziewięć publikacji pedagogicznych, w których refleksja filozoficzna odgrywa istotną, choć zróżnicowaną rolę i stwierdza na tej podstawie, że raczej nie nawiązują one do fenomenologii, ewentualnie, że „fenomenologia tematyzuje zwłaszcza, mimo uwag krytycznych, teoretyczną refleksję K. Ablewicz"13. Nawiasem mówiąc, cytowany autor przygląda się nie tej, wspominanej tutaj wcześniej pracy Krystyny Ablewicz, w której

${ }^{13}$ M. Kowalski, Pedagogika i socjologia a fenomenologie, [w:] M. Kowalski, D. Falcman, Fenomenologie: socjologia versus pedagogika, Kraków 2011, s. 118. 
perspektywa fenomenologiczna w pedagogice, jak to ona określa, jest jednym z dwu wiodących problemów, ale innej publikacji, gdzie rzeczywiście rozwijane są wątki raczej niemieckiej antropologii pedagogicznej, reprezentowanej między innymi przez Otto Bollnowa, dość luźno nawiązującej do fenomenologicznej filozofii ${ }^{14}$. Przeprowadzone przez M. Kowalskiego rozpoznanie prowadzi go do wniosku, iż:

Fenomenologie potrzebują na gruncie pedagogiki nowej, wyczerpującej artykulacji. Do tej pory podejmowane raczej zdawkowo i partykularyzowane do problemów innych od nich samych, domagają się wnikliwszego teoriopoznawczego studium ${ }^{15}$.

Jeśliby uznać, że naszkicowane postępowanie badawcze cytowanego autora miało na celu wgląd w istotowy sens zagadnienia obecności wątków fenomenologicznych $w$ pedagogice poprzez ujmowanie poznawcze intencjonalnego doświadczenia treści pedagogicznych publikacji, to wynika z niego jedynie, że nawiązania do fenomenologii nie należą do istoty pisarstwa pedagogicznego. Natomiast, wnioski sformułowane na tej podstawie w postaci twierdzeń pozytywnych są co najmniej nieostrożne. Gdyby bowiem zamiast tamtych dziewięciu opracowań uwaga wskazanego autora skierowała się na przykład na jego własną cytowaną tu pracę, Fenomenologię wychowania Jacka Filka, wspominaną wcześniej publikację K. Ablewicz, Problemy edukacji refleksyjnej Wandy Woronowicz ${ }^{16}$, Od filozoficznych podstaw wychowania do ejdetycznej filozofii wychowania Jarosława Gary, czy W poszukiwaniu rozumu pedagogicznego ${ }^{17}$ piszącego te słowa (choć jest kwestią wysoce dyskusyjną, czy autorowi wypada umieszczać skromny efekt swoich poszukiwań badawczych na wspólnej liście z tamtymi znakomitymi pozycjami), to ta sama procedura, przy takim zestawie konkretnych przejawów musiałaby niechybnie doprowadzić go do błędnego wniosku, że właśnie tak: nawiązywanie do fenomenologii jest istotową cechą refleksji pedagogicznej.

\section{Jedna czy wiele fenomenologii w naukach o edukacji?}

Nie ulega wątpliwości, że wniosek wyrażony na końcu poprzedniego paragrafu byłby błędny. Badania edukacyjne mogą być realizowane bez nawiązań do fenomenologii. Niemniej ślady jej obecności każą z kolei zastanowić

${ }^{14}$ K. Ablewicz, Teoretyczne i metodologiczne podstawy pedagogiki antropologicznej. Studium sytuacji wychowawczej, Kraków 2003.

${ }^{15}$ M. Kowalski, Pedagogika i socjologia, s. 118.

${ }^{16}$ W. Woronowicz, Problemy edukacji refleksyjnej, Koszalin 2000.

17 P. Piotrowski, W poszukiwaniu rozumu pedagogicznego. Wybrane zagadnienia metapedagogiki, Olsztyn 2012. 
się, zakładając, że nie jest konstatacja owych śladów wynikiem nieporozumienia i błędu poznawczego (a wydaje się, że można mówić przynajmniej o wątkach fenomenologicznych w refleksji nad wychowaniem), czy jest to jedna fenomenologia czy wiele. A mówiąc ostrożniej, czy jest to jeden spójny jakiś typ wątków fenomenologicznych, czy ich różnorodność niesprowadzalna do jednego typu. Zdaniem Wilfrieda Lippitza, jednego z czołowych współczesnych przedstawicieli fenomenologicznie zorientowanej nauki o wychowaniu rozwijanej w Niemczech, są trzy typy takich wątków.

Pierwszy, zdaniem tego autora, skupia się wokół motywu deskryptywnej i regionalno-ontologicznej wykładni i jedności pedagogiki ${ }^{18}$ jako dyscypliny; badanie fenomenologiczne ma ugruntować istotowy sens wychowania i w związku z tym - pedagogiki jako nad nim refleksji, czyli byłaby to swego rodzaju regionalna ontologia. Według Lippitza:

Patrząc wstecz, należy skonstatować, że oba fenomenologiczne motywy: deskryptywnej metodyki i konstytucji ontologii regionalnej, integrującej wielorodność pedagogicznych istotnych faktów, pozostały programem i nie uzyskały żadnego większego znaczenia na płaszczyźnie pedagogicznej recepcji fenomenologii ${ }^{19}$.

W gruncie rzeczy, mniej więcej to samo można by powiedzieć o fenomenologii Husserla, podmieniając tylko słowo „pedagogicznej” na „filozoficznej”. Do tego projektu należy zaliczyć wspominaną tu na początku „opisową pedagogikę" Aloysa Fischera, a także propozycje powstałe w Polsce, przedzielone ponad dziesięcioletnim dystansem czasowym, Jacka Filka ${ }^{20}$ oraz Jarosława Gary $^{21}$. Być może ten kamień odrzucony przez Wilfrieda Lippitza jest kamieniem węgielnym możliwości uznania, iż jest jedna fenomenologia w nauce o wychowaniu. Bo jeżeli twierdzenie takie byłoby słuszne, to odnosiłoby się właśnie do fenomenologii wychowania jako takiej regionalnej ontologii lub fenomenologicznego postępowania badawczego w pedagogice. Wskazywana przez Wilfrieda Lippitza okoliczność, iż taka fenomenologia pedagogiki pozostała programem i nie uzyskała większego znaczenia, nie rozstrzyga przecież wcale, iż jest to podejście błędne czy nonsensowne. Oczywiście, $\mathrm{w}$ postępowaniu badawczym skierowanym na konstytucję tej ontologii re-

${ }^{18}$ W. Lippitz, Badania fenomenologiczne w obrębie niemieckiej nauki o wychowaniu, [w:] W. Lippitz, Różnica i obcość. Studia fenomenologiczne w obrębie nauki o wychowaniu, przekł. A. Murzyn, Kraków 2005, s. 24.

19 Tamże, s. 26.

${ }^{20}$ J. Filek, Fenomenologia wychowania. Wprowadzenie, [w:] J. Filek, Filozofia jako etyka. Eseje filozoficzno-etyczne, Kraków 2001, s. 82-120.

${ }^{21} \mathrm{~J}$. Gara, Od filozoficznych podstaw wychowania do ejdetycznej filozofii wychowania, Warszawa 2009. O ile wskazany wyżej tekst J. Filka stylem filozofowania kojarzy się bardziej z fenomenologią heideggerowską, o tyle praca J. Gary nawiązuje wprost do filozofii E. Husserla i to głównie tej wyłożonej przezeń w Badaniach logicznych. 
gionalnej mogą się zdarzyć pomyłki i błędy poznawcze, opisowe, wreszcie komunikacyjne, ale takie ryzyko jest zawsze obecne i nie przesądza o niemożliwości takiej jednej fenomenologii w pedagogice. Przyjdzie jeszcze na chwilę powrócić do tego wątku, a ściślej jego uzasadnienia, pod koniec niniejszych rozważań. Póki co, pora powrócić do ujęcia zaproponowanego przez Wilfrieda Lippitza.

Drugi wymiar obecności fenomenologii w nauce o wychowaniu, o którym pisze ten badacz związany jest z motywami subiektywnymi i dyskursywno-krytycznymi, genealogicznymi i etyczno-komunikatywnymi ${ }^{22}$. Opisując ten wątek, Lippitz wyraźnie opowiada się za stanowiskiem uznającym wielość fenomenologii, zarówno $\mathrm{w}$ filozofii, jak $\mathrm{i}-\mathrm{w}$ zasadzie paralelnie - ich pedagogicznych adaptacji. Fenomenologia Edmunda Husserla nie odgrywa tu, według Lippitza, większej roli, przynajmniej bezpośrednio, jako że źródłem inspiracji są $\mathrm{w}$ pierwszym rzędzie filozoficzne projekty M. Heideggera, M. Schelera, E. Levinasa, M. Merleau-Ponty'ego, P. Ricoeura, czy Hansa-Georga Gadamera, a w drugim rzędzie, jeśli można się tak wyrazić, ich uczniów zajmujących się problematyką edukacyjną, takich jak Waldenfels, Ballauf, Schaller, Meyer-Drawe, Seewald. Nie ma tu miejsca na bliższą charakterystykę tego niezwykle rozległego obszaru nawiązań i kontynuacji. Warto może zasygnalizować jeden, dość szczególny i interesujący wątek, rozwijany także przez samego Lippitza. Chodzi mianowicie o świat dzieciństwa, czy też świat ujmowany przez dziecięcą świadomość. Jest to bardzo szczególny rodzaj niedostępnego bezpośrednio doświadczenia, podobny w znacznym stopniu do świata doświadczanego przez inną osobę, jednocześnie dostępny niegdyś bezpośrednio każdemu dorosłemu. Od tej bezpośredniej dostępności oddziela jednak pancerz teoretycznego nastawienia, będącego rezultatem wielu lat edukacji i socjalizacji, pełnienia ról i odpowiadania wymogom. Widać wyraźnie, że kwestia doświadczania świata w dziecięcej świadomości jest szczególna i w kontekście pedagogicznym, i jako problem filozofii fenomenologicznej, prowokuje także jakiś styk tych dwu terytoriów.

Wreszcie trzeci typ wątków fenomenologicznych w naukach o wychowaniu, jaki wyróżnia Wilfried Lippitz, jest związany z motywem odniesienia do świata życia codziennego ${ }^{23}$. Wymiar ten, mocno obecny także $w$ fenomenologicznej socjologii, jest zdaniem Lippitza „zasadniczą częścią fenomenologicznie zorientowanych prac w obrębie nauki o wychowaniu" ${ }^{24}$. Tak jak $\mathrm{w}$ fenomenologicznie zorientowanej socjologii, uwaga badaczy zwraca się ku sposobom prześwietlenia, jak to ujmuje wspomniany autor, strukturalnych uwarunkowań relacji między jednostką a jednostką i między jednostką a gru-

\footnotetext{
22 W. Lippitz, Badania fenomenologiczne, s. 32.

${ }^{23}$ Tamże, s. 27.

${ }^{24}$ Tamże.
} 
$\mathrm{pac}^{25}$. Wydaje się, że opowiadając się po stronie tej propozycji, Lippitz popełnia, podobnie jak wspomniany wcześniej M. Kowalski, błąd socjologizmu $\mathrm{w}$ odniesieniu do pedagogiki. Ewentualnie redukuje nauki o wychowaniu do ich jednego subregionu, mianowicie socjologii edukacji. Można zapewne nawiązywać do fenomenologii również w socjologii wychowania, jak to robił na przykład Erving Goffman. Inaczej mówiąc, prawdopodobnie można uprawiać fenomenologiczną socjologię wychowania jako pewien szczególny dział socjologii fenomenologicznej, co nie zmienia faktu, że pozostaje się wciąż na obszarze socjologii. Aby dokonać przeskoku na teren pedagogiki, trzeba by znaleźć odpowiedź na pytanie „po co?”. Po co prześwietlać strukturalne uwarunkowania relacji między jednostką a grupą? Odpowiedź brzmiąca, „żeby je poznać" jest w tym wypadku odpowiedzią zarezerwowaną dla socjologii. Natomiast odpowiedź „,aby poznawszy je móc wykorzystać do kierowania zachowaniami, ba - myślami ludzi" zarezerwowana jest tylko dla takich ideologii, które gotowe są sięgać do totalitarnej socjotechniki jako narzędzia sprawowania władzy. Odpowiedź na pytanie „po co?”, która przenosi na teren nauki o wychowaniu, jest możliwa jedynie jeśli rozpocznie się od ufundowania tego terenu na wglądzie w istotowy sens wychowania. Bo wówczas, na co w pewien sposób zwraca uwagę także K. Ablewicz ${ }^{26}$, ów wgląd w ten ogólny sens dziedzinowy, jak i w ogólny sens poszczególnych przypadków strukturalnych uwarunkowań relacji między jednostkami służy ukonstytuowaniu swego rodzaju wychowawczego nastawienia, czyli nastawienia na intencjonalne ujmowanie tego co wychowawcze, gdyż to co wychowawcze jawi się zawsze w horyzoncie aksjologicznym, który jest tu apodyktyczną koniecznością, jako warunkiem możliwości sensu edukacji. A ukonstytuowanie pedagogicznego sensu edukacji musi poprzedzać, jako warunek możliwości, asercję tożsamości sensu społecznych interakcji z ich sensem pedagogicznym. Jest to bodaj najsilniejszy argument $w$ dyskusji dotyczącej, ile fenomenologii można odnaleźć w pedagogice, a jednocześnie argument wspierający odpowiedź, że jedną, to znaczy - fenomenologię wychowania jako fenomenologię tego regionu rzeczywistości społeczno-kulturowej, wraz z jego rozmaitymi kontekstami, gdzie sens interakcji między ludźmi, sens ich spotykania, jawi się jako aksjologiczny i osobowościowotwórczy.

\section{BIBLIOGRAFIA}

Ablewicz K., Hermeneutyczno-fenomenologiczna perspektywa badań w pedagogice, Wydawnictwo Uniwersytetu Jagiellońskiego, Kraków 1994.

Ablewicz K., Teoretyczne i metodologiczne podstawy pedagogiki antropologicznej. Studium sytuacji wychowawczej, Wydawnictwo Uniwersytetu Jagiellońskiego, Kraków 2003.

${ }^{25}$ Tamże.

${ }^{26}$ K. Ablewicz, Hermeneutyczno-fenomenologiczna perspektywa badań, s. 95-97. 
Benton T., Craib I., Filozofia nauk społecznych. Od pozytywizmu do postmodernizmu, przekł. L. Rasiński, Wydawnictwo Naukowe Dolnośląskiej Szkoły Wyższej, Wrocław 2003.

Duraj-Nowakowa K., Samookreślenie pedagogów, [w:] Rozwój pedagogiki ogólnej. Interpretacje i ograniczenia kulturowe oraz poznawcze, red. A. Bogaj, Instytut Badań Edukacyjnych, Warszawa-Kielce 2001.

Filek J., Fenomenologia wychowania. Wprowadzenie, [w:] J. Filek, Filozofia jako etyka. Eseje filozoficzno-etyczne, Wydawnictwo Znak, Kraków 2001.

Flynn Th.R., Philosophy of existence 2, [w:] Twentieth-Century Continental Philosophy, red. R. Kearney, Routledge, London - New York 2005.

Gara J., Od filozoficznych podstaw wychowania do ejdetycznej filozofii wychowania, Wydawnictwo Akademii Pedagogiki Specjalnej, Warszawa 2009.

Gołaszewska M., Roman Ingarden. Życie i dzieło, Instytut Filozofii Uniwersytetu Jagiellońskiego, Kraków 1993.

Hejnicka-Bezwińska T., W poszukiwaniu tożsamości pedagogiki: świadomość teoretyczna i metodologiczna wspótczesnej pedagogiki polskiej (geneza i stan), Wydawnictwo Uczelniane Wyższej Szkoły Pedagogicznej, Bydgoszcz 1989.

Kowalski M., Pedagogika i socjologia a fenomenologie, [w:] M. Kowalski, D. Falcman, Fenomenologie: socjologia versus pedagogika, Oficyna Wydawnicza Impuls, Kraków 2011.

Kwieciński Z., Między ortodoksją a heterogenicznością teorii pedagogicznych. Ku strategiom pokonywania polskiego „opóźnienia”, [w:] Stare i nowe dylematy teorii wychowania, red. J. Górniewicz, Wydawnictwo Adam Marszałek, Torun 1993.

Kwieciński Z., Teorie pedagogiczne okresu przesilenia. Strategie przezwyciężania polskiego „opóźnienia", Kultura i Edukacja, 1993, 1(3).

Lippitz W., Badania fenomenologiczne w obrębie niemieckiej nauki o wychowaniu, [w:] W. Lippitz, Różnica i obcość. Studia fenomenologiczne w obrębie nauki o wychowaniu, przekł. A. Murzyn, Oficyna Wydawnicza Impuls, Kraków 2005.

Paulston R.G., Pedagogika porównawcza jako pole nakreślania konceptualnych map teorii i paradygmatów, przekł. Z. Melosik, K. Sobolewska-Myślik, [w:] Alternatywy myślenia o/dla edukacji. Wybór tekstów, red. Z. Kwieciński, Instytut Badań Edukacyjnych, Warszawa 2000.

Piotrowski P., W poszukiwaniu rozumu pedagogicznego. Wybrane zagadnienia metapedagogiki, Wydział Nauk Społecznych UWM, Olsztyn 2012.

Sebbah F.-D., French Phenomenology, [w:] A Companion to Phenoemnology and Existentialism, red. H.L. Dreyfus, M.A. Wrathall, Blackwell Publishing, Malden - Oxford - Carlton 2006.

Spiegelberg H., The phenomenological movement. A historical introduction, wyd. 2, t. 1, Martinus Nijhoff Publishers, The Hague 1965.

Woronowicz W., Problemy edukacji refleksyjnej, Wydawnictwo Uczelniane Bałtyckiej Wyższej Szkoły Humanistycznej, Koszalin 2000. 